\title{
СВОЙСТВА АЭРОЗОЛЕЙ \\ И АЭРОЗОЛЕОБРАЗУЮЩИХ ПРИМЕСЕЙ НИЖНЕЙ АТМОСФЕРЫ В ЛЕНИНГРАДСКОЙ ОБЛАСТИ Л.С. Ивлев
}

Главная геофизическая обсерватория им. А.И. Воейкова, Санкт-Петербург, Россия

Эл.nouma: ivlev.lev@mail.ru

Статья поступила в редакиию 27.04.2015; принята к печати 10.10.2015

Рассмотрены состав и процессы формирования аэрозолей нижних слоев атмосферы в Ленинградской области по результатам комплексных аэрозольных измерений, проведенных с 1970 по 2005 г. Отмечены выраженные суточные изменения концентраций аэрозолеобразующих газов - озона и оксидов азота. Практически во всех фракциях размеров аэрозольных частиц обнаружены полосы поглощения силикатов, карбонатов и нитратов. Из сопоставления элементного состава аэрозолей с содержанием тяжелых металлов в почве следует возможность трансграничного заноса свинца и кадмия, в то время как ртуть имеет в основном местное происхождение. Для органических компонентов аэрозолей, основная доля которых содержится в частицах с размерами <0,1 мкм, отмечаются выраженные сезонные изменения, причем максимум содержания приходится на июнь. В периоды пыления растительности концентрация органических веществ возрастает на два порядка, а размеры частиц, содержащих органические вещества, превышают 1 мкм.

Ключевые слова: тропосфера, газовые и аэрозольные примеси, состав, дневные и сезонные вариации, оптические характеристики.

\section{THE PROPERTIES OF AEROSOLS AND AEROSOL-FORMING CONTAMINANTS OF THE LOWER ATMOSPHERE IN LENINGRAD OBLAST \\ L.S. Ivlev \\ Voeikov Main Geophysical Observatory, Saint Petersburg, Russia E-mail:ivlev.lev@mail.ru}

The composition and processes of formation of aerosols of the lower atmosphere in Leningrad Oblast are discussed based on the results of comprehensive studies carried out in 1970 through 2005. Pronounced diurnal variations in the levels of the main aerosol-forming gases, nitrogen oxides and ozone have been found. In virtually all size fractions of aerosol particles, adsorption band typical of silicates, carbonates and nitrated have been found. Comparing the elemental composition of aerosols with heavy metal levels in soils suggests that transboundary lead and cadmium entry is possible, whereas mercury is mainly of local origins. The organic component of aerosols is mainly comprised of particles smaller than $0.1 \mathrm{~mm}$ and shows pronounced seasonal variations, the maximum found in June. When anthesis occurs, organic matter levels in aerosols increase by two orders of magnitude and particle sizes exceed $\mathbf{1} \mathbf{~ m m}$.

Keywords: troposphere, gaseous and aerosol contaminants, composition, diurnal and seasonal variations.

\section{Введение}

Состояние среды в значительной степени определяется воздействиями на нее различных естественных и антропогенных аэрозолей. Эти воздействия весьма разнообразны, и оценки экологического ущерба от присутствия аэрозольных частиц в атмосфере требуют знания характеристик источников аэрозолей, времени существования частиц во взвешенном состоянии, а также физико-химических процессов их образования и трансформации в воздушной и водной средах [12].

В результате химических реакций загрязняющих веществ друг с другом и атмосферными газами при солнечном освещении в аэрозолях могут образовываться вещества с более вредными для окружающей среды и человека свойствами, чем первоначально выброшенные в атмосферу [18]. Так, в результате окисления диоксида серы образуется серный ангидрид и затем серная кислота. Еще более опасные соединения возникают при взаимодействии различных углеводородов с окислами азота. Эти продукты загрязнения атмосферы принято называть вторичными. Их масса не соответствует массе выбрасываемых изначально в атмосферу загрязнений, которые в ней трансформируются, а несколько больше, в первую очередь за счет связываемых первичными загрязнениями молекул воды (гидратация, адсорбция и конденсация) и кислорода (окисление). Изменяется и время существования загрязняющих веществ в атмосфере, в основном в сторону уменьшения из-за нуклеационной генерации аэрозольных частиц, их роста и последующих процессов седиментации и вымывания [22, 27]. Принципиальных трудностей для проведения теоретических оценок концентрации и длительности их присутствия в атмосфере нет.

Есть еще тип вторичного загрязнения атмосферы, оценки присутствия которого в нижних слоях атмосферы даются весьма неопределенно, а чаще даже не учитываются. Это вещества, многократно поднимаемые в атмосферу с подстилающей поверхности, в основном адсорбированные на поверхности пылевых частиц, зачастую сильно отличающиеся от своего начального состояния.

С точки зрения общепринятой классификации атмосферных аэрозолей, поднятые с поверхности земли пылевые частицы должны называться пер- 
вичными аэрозолями, но они являются вторично поднятыми в атмосферу после их гравитационного и диффузионного осаждения, а также вымывания из атмосферы, где на них адсорбировались различные газовые молекулы и происходили химические и фотохимические реакции. По приближенным оценкам экспериментальных измерений масса вторично поднимаемых в атмосферу частиц в летнее время года составляет 20-25\% от осевших [22].

Эффект вторичного подъема частиц может существенно сказаться на оценках вклада различных источников в загрязнение нижних слоев атмосферы, в частности, когда решается обратная задача определения мощности источников загрязнении и величины нанесенного ими экологического ущерба по прямым измерениям загрязняющих компонент в приземном слое атмосферы или в осадках.

Ниже с этих позиций будут суммированы результаты многолетних комплексных аэрозольных измерений, проведенных при участии лаборатории физики аэрозолей физического факультета СанктПетербургского (Ленинградского) университета с начала 1970-х по 2005 г. в Ленинградской области, в основном на южном побережье Финского залива.

\section{Аэрозолеобразующие газы}

В процессах образования вторичных аэрозолей, то есть аэрозолей, образующихся непосредственно в атмосфере, важнейшую роль играют окислы азота и серы и озон. В городских условиях они ответственны за образование смогов. В процессах окисления различных соединений азота и серы активно участвуют молекулы озона [7, 19], причем вариации содержания аэрозолеобразующих газов неоднозначно связаны с вариациями содержания аэрозолей $[5,6,10]$. Вследствие этого временные вариации аэрозолеобразующих газов представляют интерес как показатель процессов аэрозолеобразования.

\section{Концентрация оксидов азота в приземной атмосфере}

Измерения содержания моноксида и диоксида азота на южном побережье Финского залива проводились с помощью хемилюминесцентного газового анализатора Р310.2 производства АО «ОПТЭК», измеряющего концентрацию оксидов азота в пределах $1-1000$ мкг $/ \mathrm{M}^{3}$ с частотой до 10 отсчетов в минуту. Относительная погрешность определения концентраций оксидов на всем диапазоне измерений не превышала 25\%, дискретность отсчета концентрации была 1 мкг/м ${ }^{3}$. Анализ результатов измерений позволяет сделать вывод, что средние значения содержания оксидов азота довольно низкие - порядка 3-4 мкг/ м $^{3}$. На этом фоне выделяются кратковремен-

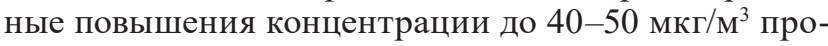
должительностью от 3-4 часов до 2-3 суток. Содержание оксидов азота в летний период гораздо выше, чем в осенний, особенно при высокой температуре воздуха в приземном слое и отсутствии облачности в первой половине дня.

Наблюдается также сезонный сдвиг суточного хода концентрации указанных газов. Для оксида азота летом характерно наличие четкого утреннего минимума в районе 7 часов $\left(3\right.$ мкг/ $\left.\mathrm{M}^{3}\right)$ и резкий

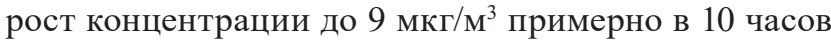
утра (время летнее). Далее NO практически не изменяется до 15 часов, а в вечернее время наблюдаются два максимума концентрации около 15 мкг/м³ в 18 и 21 час, после чего происходит быстрое уменьшение концентрации в ночное время до утреннего минимума. В первой половине осени картина суточного хода меняется (рис. 1). В несколько раз уменьшается концентрация оксида азота и, соответственно, амплитуда суточных вариаций. Вместо утреннего минимума наблюдается практически постоянный уровень со-

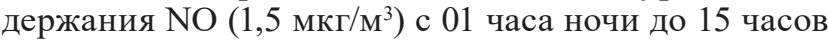
дня, хотя имеет место некоторое увеличение концентрации в утренние часы (с 08 до 13 часов). Значительное накопление оксида азота в приземном слое с максимумом около 2,5 мкг/м ${ }^{3}$ обнаруживается примерно в 20 часов.

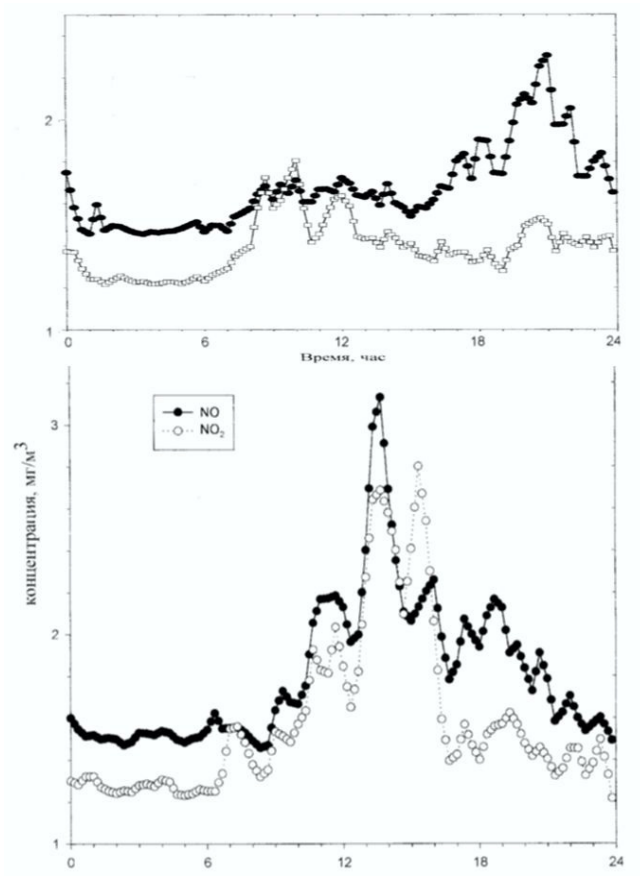

Рис. 1. Суточные вариации содержания $\mathrm{NO}$ и $\mathrm{NO}_{2}$ в приземном слое атмосферы в сентябре-октябре 1998 г. (вверху) и в ноябре-декабре (внизу), по [8]

Поздней осенью (ноябрь-начало декабря) суточный ход содержания NO вновь меняется. Он характеризуется наличием одного дневного максимума с концентрацией 3 мкг/м ${ }^{3}$ около 14 часов. Причем накопление оксида азота в атмосфере происходит достаточно быстро - с 09 до 14 часов, а затем имеют место плавное уменьшение концентрации до 24 часов и практически постоянный уровень NO в ночное

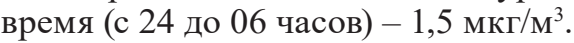

Суточный ход содержания диоксида азота имеет свои сезонные особенности. В летнее время он характеризуется наличием «предрассветного» минимума концентрации около 04-05 часов утра $\left(1,5\right.$ мкг/ $\left.{ }^{3}\right)$ и резким ростом концентрации $\mathrm{NO}_{2}$ до 11 часов $\left(4,5\right.$ мкг/ $\left.\mathrm{M}^{3}\right)$. После первого утреннего максимума происходит уменьшение концентрации до 3,5 мкг/м ${ }^{3}$ (дневной минимум) около 13-14 часов и увеличение

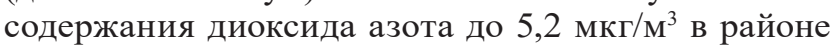
16-17 часов, то есть вечерний максимум для $\mathrm{NO}_{2}$ наблюдается раньше, чем для NO.

В первой половине осени суточные вариации содержания диоксида азота выражены слабее. Можно выделить лишь дневной максимум приблизительно в 08-12 часов $\left(1,8\right.$ мкг/M $\left.\mathbf{M}^{3}\right)$ и практически постоянный уровень концентрации в остальное время суток, хотя 
в ночное время содержание NO в среднем ниже, чем

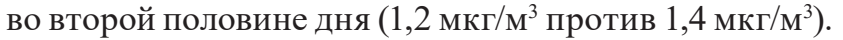
Поздней осенью суточный ход двуокиси азота практически совпадает с суточным ходом моноксида азота и имеет те же основные особенности.

Результаты, представленные на рис. 1, свидетельствуют об общем источнике оксидов азота и практически полном отсутствии фотохимического процесса преобразования $\mathrm{NO}$ в $\mathrm{NO}_{2}$ в осенне-зимний период.

Спектральный анализ вариаций оксидов азота во времени показал, что частотный спектр измеряемых концентраций содержит большое число гармоник и обладает определенной сезонной изменчивостью. Можно указать, что для $\mathrm{NO}$ и $\mathrm{NO}_{2}$ в летний и осенний периоды наблюдаются основные («синоптические») вариации с периодом 3-4 суток, наиболее четко выделяющиеся осенью. Вероятно, эти вариации связаны с синоптическими процессами в атмосфере, имеющими такой же характерный временной масштаб. Отчетливо выделяется суточная вариация и ее вторая гармоника с периодом 0,5 суток. Соотношение между этими гармониками изменяется в летний и осенний периоды, а для NO летом обе гармоники сливаются в одну с периодом 0,7 суток. По-видимому, эти изменения связаны с наложением разномасштабных процессов генерации и стока оксидов азота и могут служить иллюстрацией общей изменчивости спектра вариаций, и они не свидетельствуют о какойнибудь определенной закономерности.

Анализ короткопериодичных вариаций содержания оксидов азота позволяет выделить гармонику с периодом 1,5-2,0 часа для обоих газов в течение всего периода наблюдений. Для статистического анализа вариаций оксидов азота был применен метод нормированного размаха, или метод Херста, перспективный для статистического анализа применительно к случайным флуктуациям различных физических параметров сложных динамических систем, поскольку позволяет определить, является ли поведение системы полностью случайным, или же система обладает свойством персистентности, то есть некоторой положительной обратной связью, когда отклонения системы от среднего в одну сторону имеют тенденцию к нарастанию.

Методом нормированного размаха были обработаны временные ряды, позволившие рассчитать показатель Херста для временных рядов концентрации оксида и монооксида азота. Значения этих коэффициентов осенью практически совпадают $(0,67 \pm 0,04)$, а летом равны для $\mathrm{NO} 0,80 \pm 0,06$, а для $\mathrm{NO}_{2} 0,64 \pm 0,04$. Значение показателя Херста, равное 0,5 , соответствует полностью случайному процессу. Поэтому тот факт, что показатели Херста для содержания оксидов азота существенно превышают эту величину, указывает, что изменения концентрации газовых составляющих не являются полностью случайными, а характеризуются значительной персистентностью.

\section{Концентрации озона в приземном слое атмосферь}

Измерения содержания озона в приземном слое атмосферы проводились с осени 1984 г. на наблюдательной вышке отдела физики атмосферы НИИ физики с помощью озонометра «Dasibi» и эпизодически в других районах Ленинградской области совместно с аэрозольными измерениями фотоэлектрическим счетчиком А3-5. Результаты этих измерений под- робно обсуждались ранее [5, 9, 22]. В 1998 г. измерения содержания атмосферного озона проводились на станции комплексного экологического мониторинга в период с января по апрель. Концентрация озона определялась хемилюминесцентным озонометром «ЛОЗА-11» производства АО «ОПТЭК» с пределами измерения 1-1000 мкг/м ${ }^{3}$, относительной погрешностью на всем диапазоне не более $20 \%$ и дискретностью отсчета по уровню концентрации 1 мкг/ $\mathrm{M}^{3}$.

На рис. 2 представлены среднесуточные значения концентрации озона в приземном слое за 4 месяца измерений. Среднее содержание концентрации озона составило 40 мкг/ $\mathrm{M}^{3}$, однако уровень приземного озона отличается значительной изменчивостью. Характерная амплитуда вариаций - 20 мкг/м³. Спектральный анализ изменения содержания уровня озона выделяет синоптическую (с периодом $T=3-4$ суток) и суточную гармоники.

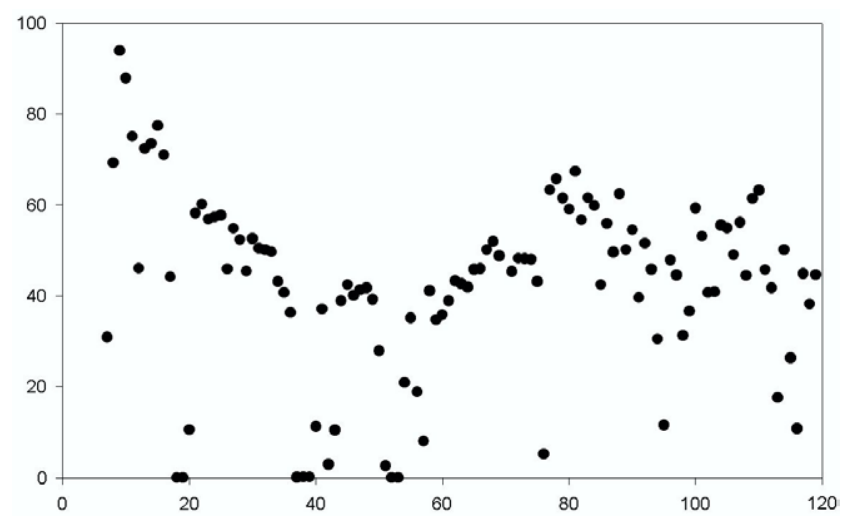

Рис. 2. Среднесуточные значения концентрации приземного озона $\left(\right.$ мкг/ $\left.\mathrm{M}^{3}\right)$.

По оси Х указаны порядковые номера дней в году, по [8]

Суточный ход концентрации озона, усредненный по периоду январь-апрель 1998 г., показывает, что

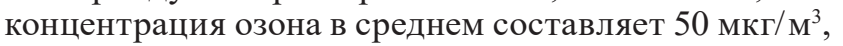
и что содержание озона растет ночью, начиная с 2-3 часов. После утреннего максимума уровень озона снижается, и минимум концентрации на уровне

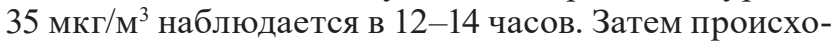
дит быстрое накопление приземного озона до дневного максимума около 15 часов (примерно 45 мкг/ $\mathrm{M}^{3}$ ). В вечернее время уровень озона демонстрирует незначительные вариации около среднего уровня 40 мкг/ $\mathbf{M}^{3}$. Следует отметить, что усреднение по большому периоду измерений приводит к существенному сглаживанию вариаций содержания приземного озона и уменьшению амплитуды этих колебаний, что искажает реальную картину. Более детальный анализ данных показывает, что наблюдаются периоды, когда суточные изменения концентрации озона выражены очень сильно, и периоды, когда уровень озона меняется незначительно (обычно в этих случаях

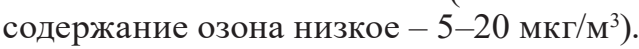

Обработка полученных временных рядов концентрации приземного озона методом нормированного размаха позволила рассчитать показатель Херста для флуктуаций его содержания за период январь-апрель 1998 г. За указанный период он составил 0,94 $\pm 0,06$, что указывает на наличие долговременной статистической зависимости между вариациями содержания приземного озона. 


\section{Тропосферные аэрозоли}

Основные исследования тропосферных и приземных аэрозолей в начале 1970-х гг. выполнялись в рамках программ КЭНЭКС и ГАРЭКС, координируемых Государственной геофизической обсерваторией им. А.И. Воейкова [22]. Комплекс аппаратуры, установленный на самолете ИЛ-18 и использованный для измерения аэрозольных характеристик, включал приборы прямого измерения аэрозолей с помощью забора аэрозольных частиц на фильтровую ткань и импакторные подложки для последующего изучения этих проб на оптическом и электронном микроскопах, а также путем анализа отдельных элементов на рентгено-флуоресцентном спектрометре; фотоэлектрический счетчик А3-5, измеряющий частицы c $r>0,2$ мкм; актинометр, позволяющий измерять оптические толщи вышележащих слоев атмосферы, коротковолновый солнечный спектрометр КСС-2. В наземных измерениях кроме перечисленных приборов в приземном слое использовались аэрозольные мембранные и кварцевые фильтры (для изучения органических компонент).

\section{Источники и пространственно-временные характеристики аэрозолей}

Общие характеристики атмосферных аэрозолей in situ определяются их источниками, которые ответственны за их начальные физико-химические свойства, и эволюционными атмосферными процессами. Следовательно, очень важно при измерениях учитывать местонахождение локальных источников аэрозолей и адвективный перенос частиц $[4,14]$.

Наиболее простым и надежным способом идентификации источников аэрозолей и путей их трансформации и выведения из атмосферы является картирование воздушных потоков и определение загрязнения почвы характерными аэрозольными компонентами, например, вредными химическими соединениями или характерными тяжелыми элементами. Определенную сложность в идентификации источников создает вторичная генерация аэрозолей, осевших на поверхности различных объектов и почв, возникающая в результате неравномерного нагрева объектов и почвы, а также при ветре. Для этих вторичных аэрозолей вклад от определенных первичных промышленных источников может достигать $25 \%$ и более [5, 7]. Идентификация источников аэрозолей по химическим соединениям эффективна вблизи источника при явном превышении выбрасываемого вещества над фоновым или когда хорошо известна эволюция химического состава аэрозольного вещества. В частности, она наиболее успешна для источников, содержащих органические соединения [22]. Идентификация источников по морфологической структуре частиц эффективна для различных специфических аэрозолей, например, техногенного происхождения, для кристаллических и фракталоподобных частиц. Хорошо идентифицируются сажевые частицы [16].

Универсальным методом идентификации источников является анализ элементного состава. Этот способ в ряде случаев оказывается достаточно надежным, если для источника существуют характерные соотношения концентраций некоторых элементов, что позволяет написать простые линейные уравнения и решать систему этих уравнений. В большинстве случаев характерные соотношения концентраций элементов сохраняются или слабо меняются для всего спектра размеров частиц. Однако для эффективного внедрения этого способа необходим надежный и достаточно полный банк данных по элементному составу возможных источников аэрозолей.

Основными источниками аэрозольного загрязнения окружающей среды Ленинградской области являются $[15,17]$ :

- трансграничный перенос загрязняющих веществ из соседних регионов воздушными потоками в верхней атмосфере;

- техногенные выбросы индустриальных центров региона (в первую очередь, мегаполиса Санкт-Петербурга), распространяемые воздушными потоками в нижней атмосфере;

- автомобильный транспорт на основных магистралях области.

На карте-схеме Ленинградской области (рис. 3) изображены сезонные розы ветров в нижней атмосфере, характерные для всей области [17], и господствующее направление трансграничного переноса на область атмосферных потоков в верхней атмосфере [17]. Здесь же отображены основные транспортные магистрали с наиболее интенсивным движением автомобильного и железнодорожного транспорта.

В соответствии со спецификой почвенно-климатических условий на территории области можно выделить пять районов: 1 - Пригородный, 2 - Юго-западный, 3 - Карельский перешеек, 4 - Восточный, 5 - Северо-восточный.

По климатическим данным в Ленинградской области в среднем за год преобладают ветры Юго-западного направления с небольшим превышением повторяемости западного румба; частота ветров северного и восточного направлений значительно меньше [17]. Из анализа конфигурации розы ветров (рис. 3, 4) следует, что над всеми районами области зимой в нижней атмосфере устойчиво преобладают ветра юго-западных, а летом - западных направлений. Господствующим направлением трансграничного переноса воздушных потоков в верхней атмосфере, обеспечивающих импорт загрязняющих аэрозолей из соседних регионов в течение всего года, является юго-западное направление.

О преимущественном характере загрязненности нижних слоев атмосферы Ленинградской области свидетельствуют пробы осадков, полученных в обсерватории Воейково. Исследовались пробы осадков, в значительной части которых после добавления индикатора развивалась розовая или фиолетовая окраска раствора (кислая среда). Качественная реакция в этих случаях показывает диапазон $\mathrm{pH}<5,3$. Щелочной характер осадков определяется зеленой окраской, которая соответствует диапазону $\mathrm{pH}>5,8$. Переход окраски индикатора от фиолетового к зеленому через серый цвет происходит примерно в диапазоне $5,3>\mathrm{pH}<5,8$, который условно назовем равновесным. Точка перехода окраски индикатора соответствует $\mathrm{pH}=5,4$ [5]. В мегаполисе при ветрах всех направлений отмечались осадки как щелочного, так и кислотного типа, реже - равновесного. Пробы щелочного характера составляли $63 \%$, кислого - 30, равновесного - 7\%. Примерно такое же соотношение сохраняется и для отдельных 


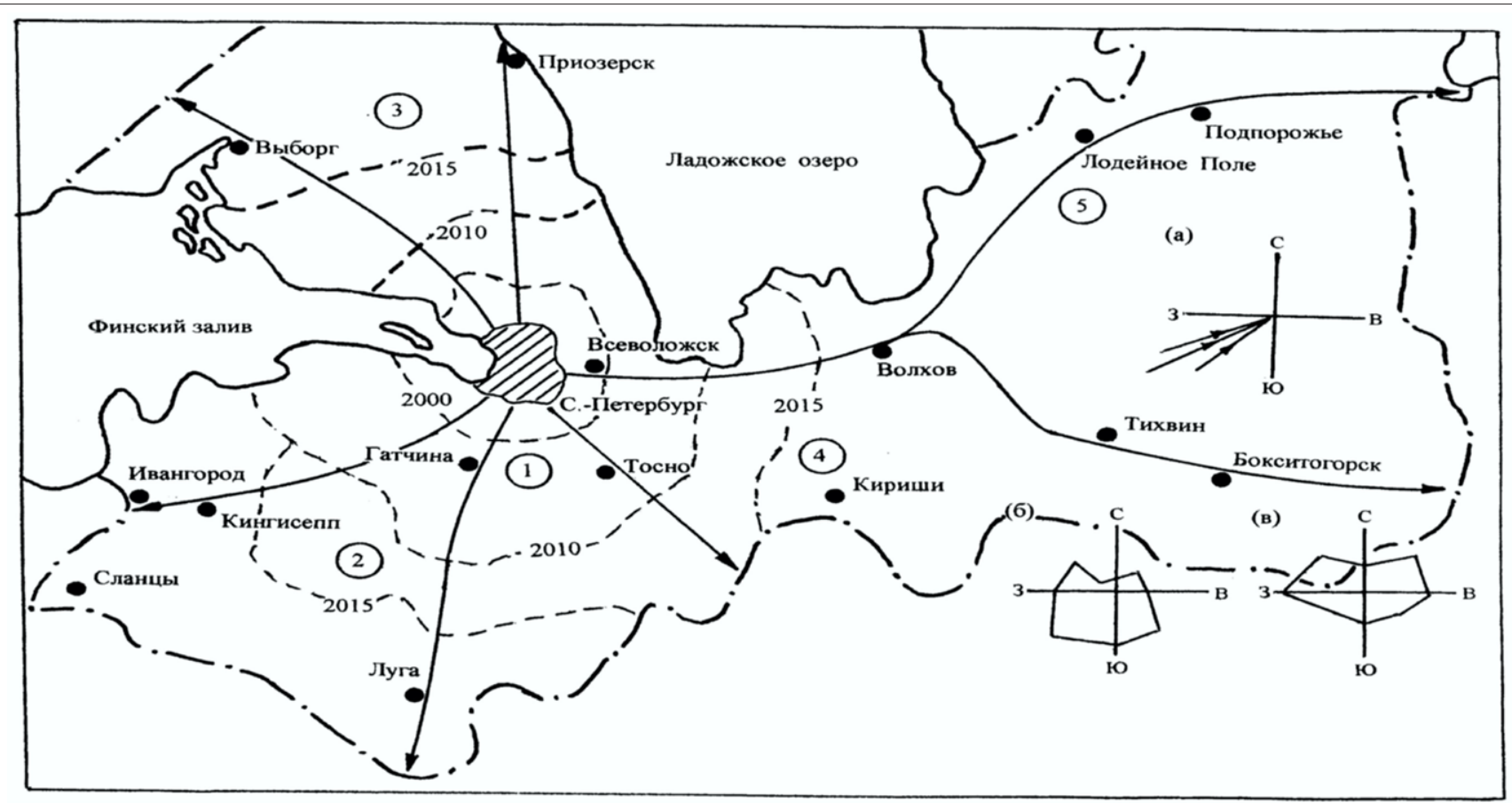

Рис. 3. Карта-схема Ленинградской области с изображением господствующих направлений трансграничного переноса воздушных потоков (a); розы ветров воздушных потоков для января (б) и июля (в); транспортные магистрали с интенсивным движением $(\longrightarrow)$

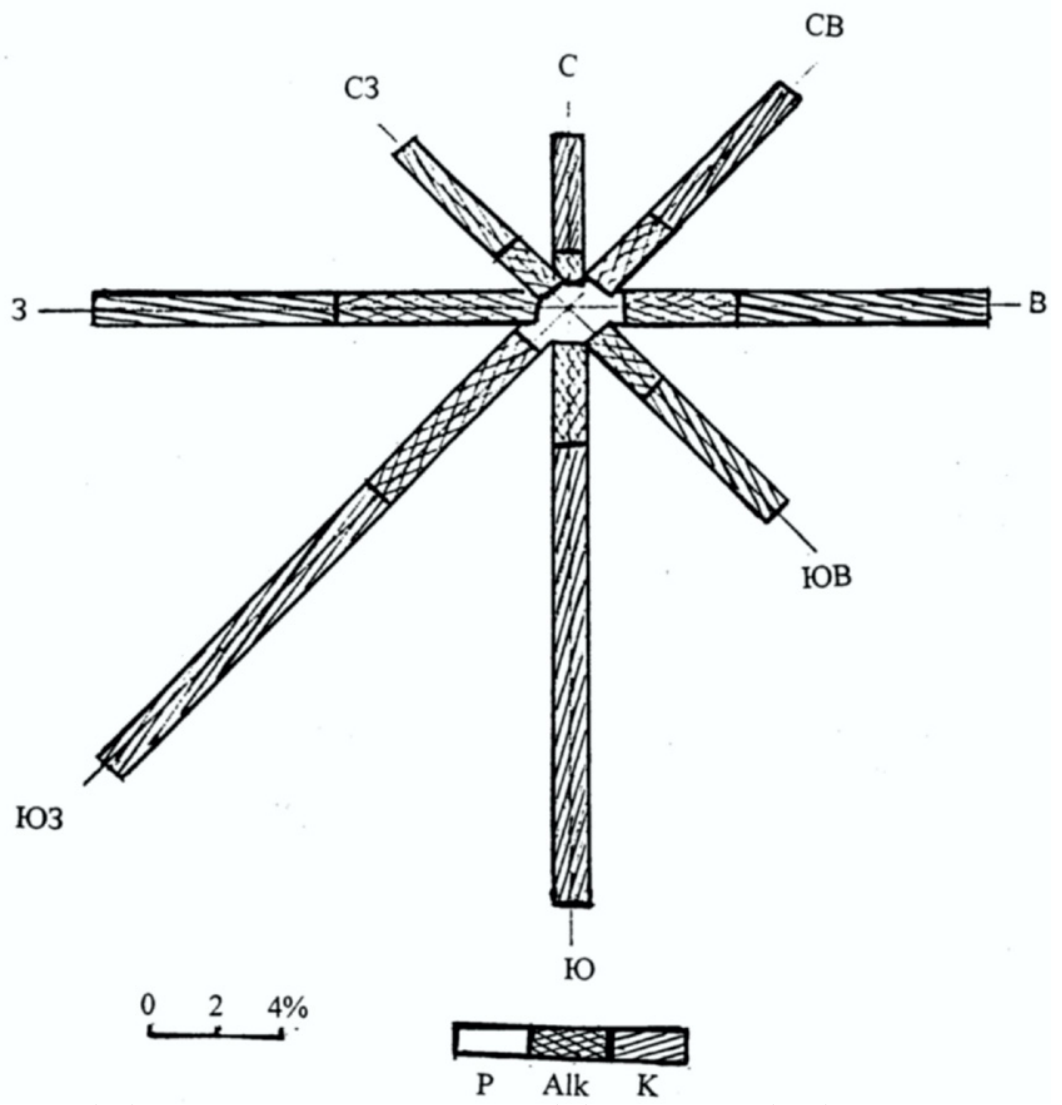

Рис. 4. Повторяемость ветра (\%) у земли, а также кислотного (K), щелочного (Alk) и равновесного (P) типов осадков при различных направлениях ветра на ст. Воейково [12] 
направлений ветра, в том числе и для преобладающих направлений.

За пределами города уже на небольшом удалении от него соотношение повторяемостей кислых и щелочных осадков изменяется. Так, в Воейково преобладающими становятся кислые осадки, их повторяемость здесь составляет 64\%, а щелочных - только 27 , равновесных - 9\%. Заметное увеличение доли щелочных осадков в Воейково при западных и юго-западных ветрах (до 30-40\%) можно объяснить влиянием города. При всех направлениях ветра повторяемость кислых проб осадков составляет 60-80\%. Соотношение равновесного, кислотного и щелочного типов осадков в мегаполисе примерно равно $\mathrm{P}: \mathrm{K}: \mathrm{Alk}=$ $1: 2: 3$ (преобладание кислого типа), тогда как по данным ст. Воейково (область) $\mathrm{P}: \mathrm{K}: \mathrm{Alk}=1: 3: 2$ практически при любых направлениях ветра, то есть для области характерен щелочной характер осадков и, следовательно, атмосферных аэрозольных и газовых примесей.

\section{Дисперсность приземных аэрозолей}

Для большинства данных по дисперсности частиц характерна относительно высокая стабильность функции распределения частиц по размерам в приземном слое для определенного типа подстилающей поверхности. Эта функция лишь очень приближенно может быть описана формулой Юнге. Практически всегда в приземном слое присутствует большое количество гигантских частиц, превышающее их концентрацию, получаемую из формулы Юнге с параметром $v=3,5$.

Функции распределения аэрозольных частиц по размерам для проб, взятых вблизи промышленных источников, менее стабильны. Характерно наличие очень мелкодисперсной фракции и рыхлых конгломератов частиц, часто значительно превышающих размеры нескольких микрометров. Вид функции распределения в данном случае сравнительно мало зависит от высоты проведения измерений.

Следует отметить достаточно хорошее соответствие общих результатов по дисперсности и счетной концентрации для разных пунктов наблюдений, что позволяет считать представленные выше результаты характерными для региона.

По данным измерений фотоэлектрическими счетчиками обнаруживается заметный суточный ход счетной концентрации аэрозольных частиц в приземном слое, обусловленный режимом генерации аэрозольного вещества и температурным режимом подстилающей поверхности. Как правило, наблюдаются два максимума счетной концентрации аэрозолей в приземном слое в течение суток: утренний, появление которого связано с активной генерацией аэрозольных частиц, и вечерний, обусловленный оседанием частиц из более высоких слоев воздуха. При этом наблюдается некоторая трансформация спектра размеров аэрозольных частиц в течение суток. При представлении реальных спектров размеров аэрозольных частиц с помощью двухмодового распределения $\left(r_{\mathrm{oi}}=0,05-0,15\right.$ мкм, $r_{\text {оз }}=4-12$ мкм) характерны суточные вариации модальных радиусов, представленные на рис. 5.

Для $r_{\text {оі }}$ отмечаются три максимума - в утренние, послеполуденные и в ночные часы. Для $r$ оз такой упорядоченности нет. Обычно наблюдается достаточно отчетливый утренний (предполуденный) максимум, обусловленный, вероятно, появлением ветра.

Следует отметить, что поведение удельного содержания частиц с размерами $r \sim 0,25$ мкм неустойчиво: при изменении высоты может наблюдаться как сильное увеличение концентрации этих частиц на больших высотах, так и уменьшение.

Наблюдаются значительные отклонения функции распределения аэрозольных частиц по размерам от формулы Юнге в диапазоне гигантских частиц (повышенное содержание). Частицы имеют, как правило, овальную форму.

При анализе проб аэрозольных частиц под электронным микроскопом наблюдается пониженное, по сравнению с юнговским, содержание частиц с радиусом $r<0,1$ мкм. Максимум в распределении частиц по размерам приходится на $r \cong 0,05$ мкм. Данные по тропосферному аэрозолю хорошо согласуются с результатами измерений Блиффорда [20].

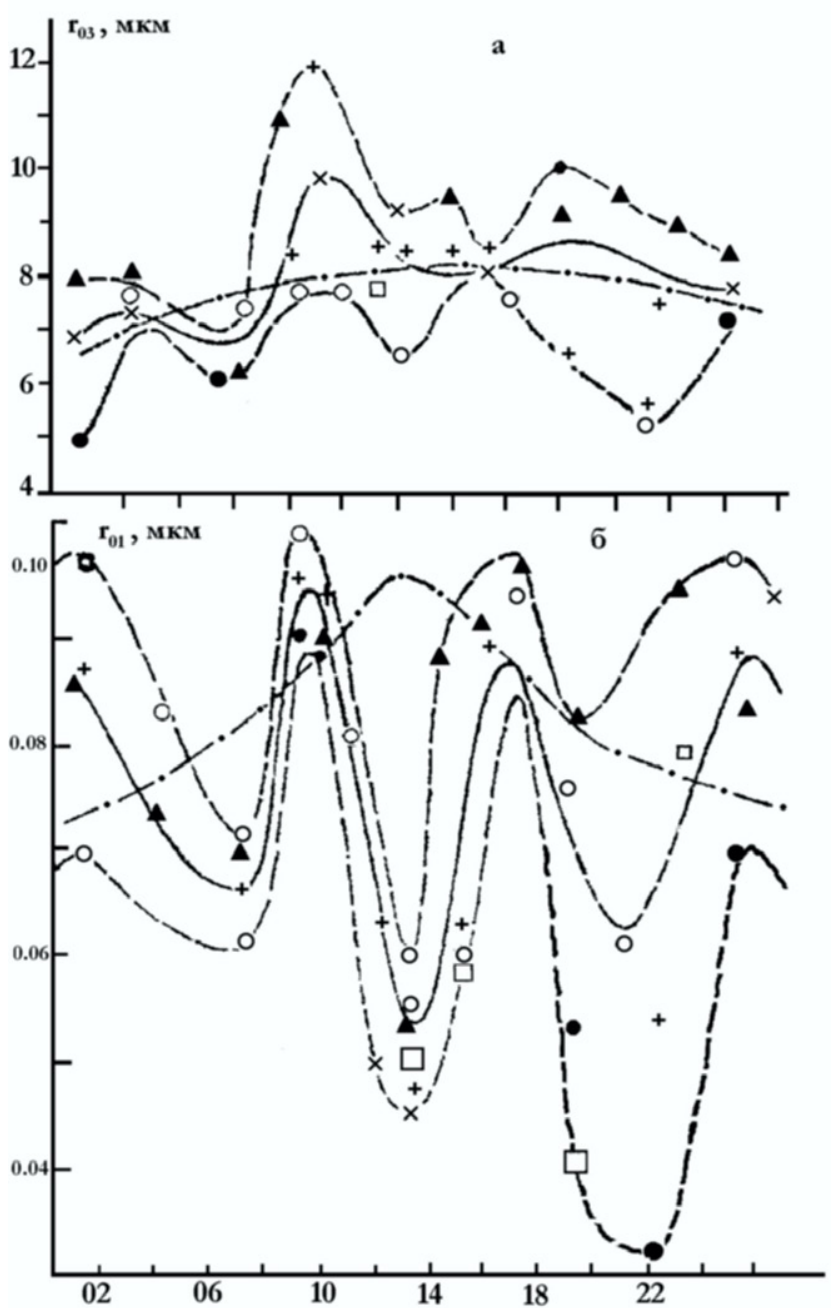

Рис. 5. Суточные хода модальных радиусов $r_{01}(6), r_{03}(a)$ аэрозольных частиц (летне-осенний период):

- - - тропосфера, приземный слой:

\ Старый Петергоф и другие районы Ленинградской области.

Для сравнения приводятся данные измерений в других регионах:

О - г. Рыльск, + - Каракумы, X - Нефтяные Камни, Карадаг, $\square$ - Адлер [26] 


\section{Наземные измерения структуры аэрозолей}

Основной массив данных по дисперсности приземных аэрозолей был получен с помощью фотоэлектрического счетчика А3-5 для диапазона размеров частиц от 0,2 мкм до 10 мкм. Самолетные измерения аэрозолей проводились над Ладожским озером в весенне-летний период 2002 г. Осенью 1998 г. были проведены измерения дисперсности аэрозольных частиц в Финском заливе (о-ва Б. Березовый, Соммерс и Гогланд). Отдельные измерения проводились на каскадном импакторе с германиевой подложкой и на каскадных фильтрах нуклеопор для ИК-анализа на содержание органических компонент. Для элементного анализа аэрозолей применялись пробы на Петряновских фильтрах, а в отдельных случаях на 4 каскадных фильтрах, предоставленных Б.И. Огородниковым (НИФХИ им. Л.Я. Карпова). Более 600 проб проанализированы с помощью рентгено-флуоресцентного метода. В среднем использовалось 20 фильтровых проб в год, кроме 1976 и 1977 гг., когда количество проб было 5 и 7 соответственно. Объемы прокаченного воздуха в пробах $-3-5 \mathrm{~m}^{3}$.

Проведенные исследования дали богатую информацию о пространственно-временной структуре, химическом составе и микроструктуре аэрозолей [9]. К сожалению, эта информация довольно противоречива. В первую очередь это касается оценки вклада таких источников, как морская поверхность, почва и реакции образования аэрозольных частиц из газа. Так, результаты «морских» программ КЭНЭКС-1973 и АТЭП [3, 22] свидетельствуют о том, что вклад аэрозолей морского происхождения в общее содержание аэрозолей невелик (около 10\%), тогда как другие авторы $[5,21]$ полагают, что доля морских аэрозолей значительно выше (30\%). В монографии [5] почве как источнику аэрозолей придается более существенное значение, чем в работах $[21,28]$, где ведущая роль в образовании аэрозолей отведена фотохимическим реакциям, в первую очередь, образованию частиц из органических газов. В $[8,24]$ вклад фотохимических аэрозолей в общее содержание атмосферных аэрозолей предполагается очень небольшим (около 5\%). Оценки вклада других источников аэрозолей достаточно близки (вулканическая пыль - 0,1-0,5\%; лесные пожары - 2-5; сернистые соединения - 9-25; соединения азота - 5-15; антропогенные частицы 5-10\%). Следует отметить, что эти среднеглобальные оценки могут совершенно не соответствовать роли различных источников в разных местах и в разное время года.

Весьма важный вывод был получен относительно пространственной структуры поля концентрации аэрозолей. Были твердо установлены факты слоистой вертикальной структуры аэрозолей и широкого диапазона изменения концентрации аэрозолей не только с высотой, но и в горизонтальном направлении (для частиц радиусом $r>0,2$ мкм от $\mathrm{N}=1 \mathrm{~cm}^{-3}$ до $\mathrm{N}=1000$ $\left.\mathrm{cm}^{-3}\right)[1,13]$.

\section{Элементный состав аэрозолей}

Среднестатистический элементный состав осадков и облачных капель в слоисто-кучевых облаках по измерениям на Северо-Западе Европейской территории России представлен в табл. 1 [12].

Измерения проводились в удалении от крупных промышленных производств и городов. В приведенных данных бросается в глаза большой разброс по большинству элементов, особенно в облачной воде. Судя по содержанию $\mathrm{Na}, \mathrm{S}, \mathrm{Cl}$, сернистокислые и хлористоводородные соединения в облаках находятся в близких концентрациях. Это свидетельствует о большом вкладе морских аэрозолей этого региона в их содержание, высокие концентрации Са - о значительной доле почвенных аэрозолей.

Полученные за длительный период измерений результаты позволяют сделать некоторые общие выводы о дисперсности, составе и пространственновременной структуре аэрозолей приземного слоя атмосферы, особенно в районах близости Финского

Элементный состав осадков и облачных капель, мкг/л $[4,10,20]$

\begin{tabular}{|l|c|c|c|}
\hline \multicolumn{1}{|c|}{ Элемент } & Облачные капли & Облачная вода & Ледяные отложения \\
\hline $\mathrm{H}$ & $1,1 \times 10^{8}$ & $1,1 \times 10^{8}$ & $8,83 \times 10^{8}$ \\
\hline $\mathrm{O}$ & $8,83 \times 10^{8}$ & $8,83 \times 10^{8}$ & $\bullet$ \\
\hline $\mathrm{Na}$ & $1,35 \times 10^{3}$ & $(8,2-25) \times 10^{2}$ & $\bullet$ \\
\hline $\mathrm{S}$ & $1,5 \times 10^{3}$ & $(0,2-9,0) \times 10^{4}$ & $\bullet$ \\
\hline $\mathrm{Cl}$ & $1,45 \times 10^{3}$ & $(8,2-27) \times 10^{3}$ & $\bullet$ \\
\hline $\mathrm{K}$ & $\bullet$ & $(2,5-8) \times 10^{3}$ & $2 \times 102-2 \times 10^{3}$ \\
\hline $\mathrm{Ca}$ & $6,8 \times 10^{2}$ & $(1,2-3,5) \times 10^{3}$ & $9-700$ \\
\hline $\mathrm{Sc}$ & $\bullet$ & $(0,8-5,0) \times 10^{3}$ & $1,7-40$ \\
\hline $\mathrm{Ti}$ & $1-15$ & $\bullet$ & $100-650$ \\
\hline $\mathrm{V}$ & $0,8-1,0$ & $\bullet$ & $1,5-11$ \\
\hline $\mathrm{Cr}$ & $2-2,5$ & $\bullet$ & $3-16$ \\
\hline $\mathrm{Mn}$ & $3-12$ & $\bullet$ & $7-32$ \\
\hline $\mathrm{Co}$ & $\bullet$ & 0,3 & $8-25$ \\
\hline $\mathrm{Ni}$ & $0,20-4,0$ & 1,4 & $\bullet$ \\
\hline $\mathrm{Cu}$ & $0,9-21,0$ & $\bullet$ & $\bullet$ \\
\hline $\mathrm{Zn}$ & $\bullet$ & $0,5-0,4$ & $\bullet$ \\
\hline $\mathrm{Pb}$ & $0,2-3,4$ & $0-0,15$ & \\
\hline $\mathrm{Ag}$ & $0-0,24$ & & $\bullet$ \\
\hline
\end{tabular}

Примечание: •- отсутствие данных. 
залива. Практически во всех фракциях размеров обнаруживаются полосы поглощения силикатов, карбонатов и нитратов. Если общая весовая концентрация

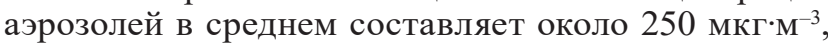
то на долю кварцевых частиц приходится около 100

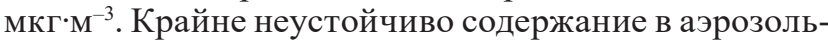
ных частицах таких элементов, как $\mathrm{Fe}, \mathrm{Ca}, \mathrm{Zn}$. Основной компонентой аэрозолей являются частицы почвы. Здесь наблюдалось более высокое содержание таких элементов, как $\mathrm{Ca}, \mathrm{Al}, \mathrm{Mg}$. Большая часть частиц (по массе) имеют минеральное происхождение.

Вариации концентраций литогенных (почвенных) элементов определяются их содержанием в земной коре. Поэтому выделение в пробах воздуха и атмосферных осадков группы естественных почвенных элементов на основе критерия большой величины концентрации является закономерным следствием геохимического состава и свидетельствует о естественном почвенном источнике поступления этих элементов в атмосферу.

Это подтверждает и корреляционный анализ. Вопервых, содержание большинства элементов литогенной (почвенной) группы в атмосфере изменяется во времени и на местности сходным образом, то есть существует общий источник этих элементов. Исключение из правила - сера, содержание которой в атмосфере изменяется своеобразно, очевидно, из-за изменчивости содержания сернистого газа в воздухе. Во-вторых, элементы почвенной группы в основном находятся в определенном соотношении друг с другом, стабильном в течение долгого времени (по крайней мере, несколько месяцев) на значительной площади. Возможные техногенные поступления при этом практически незаметны на фоне естественных содержаний элементов, за исключением некоторых случаев.

Более сложная ситуация с микроэлементами, по концентрации значительно уступающими литогенной (почвенной) группе. На фоне малых величин концентраций этих элементов как в земной коре, так и в атмосфере поступления данных элементов из техногенных источников могут существенно изменить их содержание в воздухе.

Концентрации макроэлементов Al, Si, P, K, Ca, Ti, $\mathrm{Fe}$ в каждой серии измерений меняются очень похожим образом, что указывает на общий источник их поступления в атмосферу. С учетом большого абсолютного содержания этих элементов в атмосфере и хорошей корреляции пространственно-временных зависимостей их концентраций в проведенных измерениях можно рассматривать $\mathrm{Al}, \mathrm{Si}, \mathrm{P}, \mathrm{K}, \mathrm{Ca}, \mathrm{Ti}$, $\mathrm{Fe}$ как элементы естественного почвенного происхождения. Почти во всех пунктах наблюдений к этой группе примыкают микроэлементы Mn и Sr. Bce перечисленные элементы составляют наиболее стабильную часть литогенной группы [12].

На разных этапах наблюдений к группе естественных компонентов добавлялись другие микроэлементы со сходными вариациями. Вероятно, что для этих микроэлементов процесс поступления в атмосферу обусловлен влиянием как естественных источников, так и техногенных, и только конкретные условия в пункте наблюдения определяют доминанту в этом процессе. В зимних измерениях элементы $\mathrm{Cr}, \mathrm{Cu}, \mathrm{Y}$, $\mathrm{Zr}$, вариации которых в определенной степени соответствовали вариациям элементов литогенной груп-

Концентрации элементов в пробах атмосферного воздуха и осадков (снега), взятых в октябре-ноябре 1997 г. на южном побережье Финского залива (I - Сосновый Бор; II - Систо-Палкино; III - Усть-Луга)

\begin{tabular}{|c|c|c|c|c|c|c|}
\hline \multirow[b]{2}{*}{ Элемент } & \multicolumn{3}{|c|}{ Пробы воздуха, нг/м ${ }^{3}$} & \multicolumn{3}{|c|}{ Пробы снега, мкг/л } \\
\hline & $\begin{array}{c}I \\
29.10 .97 \\
\end{array}$ & $\begin{array}{c}\text { II } \\
29.10 .97 \\
\end{array}$ & $\begin{array}{c}\text { III } \\
3.11 .97\end{array}$ & $\begin{array}{c}I \\
29.10 .97 \\
\end{array}$ & $\begin{array}{c}\text { II } \\
29.10 .97 \\
\end{array}$ & $\begin{array}{c}\text { III } \\
3.11 .97 \\
\end{array}$ \\
\hline $\mathrm{Al}$ & - & - & - & - & - & 5000 \\
\hline $\mathrm{Si}$ & 2360 & 700 & 2560 & 1600 & 170 & 74700 \\
\hline $\mathrm{S}$ & 6730 & 990 & - & 690 & 90 & 1280 \\
\hline $\mathrm{Cl}$ & - & - & - & 80 & - & 140 \\
\hline $\mathrm{K}$ & - & - & 590 & 21 & 7 & 3080 \\
\hline $\mathrm{Ca}$ & 645 & 120 & 555 & 569 & 120 & 6340 \\
\hline $\mathrm{Ti}$ & 49 & 247 & 118 & 123 & 50 & 860 \\
\hline $\mathrm{Cr}$ & - & - & - & 10 & 16 & 86 \\
\hline $\mathrm{Mn}$ & 112 & 95 & 103 & 7 & 4 & 119 \\
\hline $\mathrm{Fe}$ & 135 & 99 & 340 & 103 & 15 & 6650 \\
\hline $\mathrm{Ni}$ & 60 & - & - & 30 & 15 & 13 \\
\hline $\mathrm{Cu}$ & 204 & 43 & 125 & 13 & 257 & 58 \\
\hline $\mathrm{Zn}$ & 41 & 320 & 88 & 35 & $<3$ & 55 \\
\hline $\mathrm{Br}$ & - & - & - & 3 & 4 & - \\
\hline $\mathrm{Se}$ & - & - & 23 & 3 & 2 & - \\
\hline $\mathrm{Rb}$ & 6 & - & 15 & 2 & 1 & 122 \\
\hline $\mathrm{Sr}$ & 43 & 20 & 9 & 2 & 1 & 128 \\
\hline $\mathrm{Zr}$ & 31 & 26 & 485 & 8 & 4 & 103 \\
\hline $\mathrm{Pb}$ & 80 & 39 & 51 & 6 & $<3$ & 63 \\
\hline
\end{tabular}

Примечание. Во всех случаях отобран свежевыпавший снег, но в пос. Усть-Луга - снежная крупа с большим зернистым осадком после

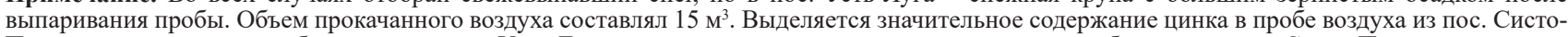
Палкино и циркония в пробе воздуха из пос. Усть-Луга, а также повышенное содержание меди в пробе снега из пос. Систо-Палкино. 
пы, явно подвергались сторонним возмущениям.

В серии зимних измерений в одну четко обособившуюся группу вошли $\mathrm{Ni}, \mathrm{Ga}, \mathrm{Se}, \mathrm{Br}, \mathrm{Rb}, \mathrm{Pb}$, а в другую - Cr, Zn, Zr; в весенних измерениях - Cr, Mn, $\mathrm{Rb}$, Th.

При рассмотрении результатов анализа дождевой воды и водных осадков $\mathrm{Cr}, \mathrm{Ni}$, а также $\mathrm{Cr}, \mathrm{Cu}, \mathrm{Zn}$ явно выделяются в отдельные группы, концентрации которых изменяются во времени отличным от литогенных (почвенных) элементов образом. Так как многие из этих микроэлементов уже отмечались как коррелирующие (хорошо или частично) с вариациями естественных компонент, то, видимо, в данных пунктах и в данное время их поступление в атмосферу зависело, главным образом, не от литогенных источников, а контролировалось другими источниками [9].

Если для осенне-зимнего периода (октябрь-март) заметен значительный вклад техногенных аэрозолей, то для летнего периода локальные местные источники аэрозольных частиц практически отсутствуют. Только при наличии переноса воздушных масс со стороны Санкт-Петербурга наблюдается определенное влияние большого города. Такие ситуации имеют место, в основном, в предутренние и утренние часы.

О последствиях наличия нелитогенных элементов в составе аэрозолей для состояния среды можно судить по результатам выборочного анализа химического состава почв различных районов Ленинградской области, проведенного Северо-западным научным центром Российской академии сельскохозяйственных наук [15]. Они свидетельствуют о наличие в них целого спектра тяжелых металлов $(\mathrm{Cd}, \mathrm{Cr}, \mathrm{Ni}, \mathrm{Pb}$ и $\mathrm{Hg}$ ) и о значительной пространственной неоднородности их распределения по территории области. Высокая вариабельность содержания тяжелых металлов, зарегистрированная при данных измерениях, создает трудности для их классификации. По этой причине в табл. 3 включены лишь сведения о представленности тяжелых металлов в районах области.

Табл. 3

Представленность тяжелых металлов в районах Ленинградской области

\begin{tabular}{|l|l|}
\hline Район области & Тяжелые металлы \\
\hline Пригородный & $\begin{array}{l}\mathrm{Pb}, \mathrm{Cd}, \mathrm{Hg}, \mathrm{Cr}, \mathrm{Fe}, \mathrm{Ni}, \mathrm{Zn}, \mathrm{Cu}, \\
\mathrm{Mn}, \mathrm{Al}, \mathrm{As}\end{array}$ \\
\hline Юго-западный & $\mathrm{Pb}, \mathrm{Cd}, \mathrm{Hg}, \mathrm{Cr}, \mathrm{Ni}, \mathrm{Zn}, \mathrm{Cu}$ \\
\hline Карельский перешеек & $\mathrm{Pb}, \mathrm{Cd}, \mathrm{Cr}, \mathrm{As}$ \\
\hline Восточный & $\mathrm{Pb}, \mathrm{Cd}, \mathrm{Cr}, \mathrm{Zn}, \mathrm{Cu}$ \\
\hline Северо-восточный & $\mathrm{Pb}, \mathrm{Cd}, \mathrm{Hg}, \mathrm{Cr}, \mathrm{Ni}$ \\
\hline
\end{tabular}

При фоновом для всего северо-западного региона России выпадении $\mathrm{Pb}$, равным 1,86 кг км $^{-2}$ в год, полученные расчетным путем величины выпадений $\mathrm{Pb}$ на территорию Ленинградской области в 1999 г. были повсеместно выше критических. При этом содержание $\mathrm{Pb}\left(4,5\right.$ кг·км ${ }^{-2}$ в год) на территории Пригородного района области почти в два раза выше, чем на территориях Юго-западного и Северо-восточного районов, а также на Карельском перешейке. Высокая неравномерность распределения выпадения $\mathrm{Pb}$ по районам области определяется господствующими направлениями воздушных потоков в нижней атмосфере северо-западного региона России: преоблада- ние западного направления в летний период и югозападного - в зимний.

По данным Ленкомприроды в 1999 г. на территорию области поступило от собственных источников примерно половина общего количества $\mathrm{Pb}$. Следовательно, в настоящее время одним из источников загрязнения почв Ленинградской области $\mathrm{Pb}$ следует считать в равной мере как его импорт из стран Западной Европы путем трансграничного переноса воздушных потоков в верхней атмосфере, так и атмосферные выбросы промышленных предприятий области, в первую очередь мегаполиса Санкт-Петербурга.

Общепринято считать, что основными региональными источниками поступления $\mathrm{Pb}$ на почвы области являются продукты сгорания углеводородного топлива транспорта с двигателями внутреннего сгорания (автомобильного и железнодорожного). Распределения сезонных ветров по районам области (рис. 4) показывают, что практически на всей территории области направления воздушных потоков в нижней атмосфере и направления основных транспортных магистралей пересекаются почти под прямыми углами. Такое их взаимное пространственное расположение должно благоприятствовать выносу $\mathrm{Pb}$ с транспортных магистралей на расположенные по соседству земли. Действительно, приведенные в табл. 4 данные о содержании $\mathrm{Pb}$ в почвах по районам области свидетельствуют о более высоком содержании Рb в почвах Пригородного района, по которому проходит максимальное число транспортных магистралей.

Табл. 4

Поступление свинца и кадмия в почвы Ленинградской области

\begin{tabular}{|c|c|c|}
\hline \multirow{2}{*}{ Район области } & \multicolumn{2}{|c|}{ Кг' км ${ }^{-2}$ в год } \\
\hline & $\mathbf{P b}$ & Cd \\
\hline Пригородный & 4,5 & 0,069 \\
\hline Юго-западный & 2,7 & 0,041 \\
\hline Карельский перешеек & 2,0 & 0,026 \\
\hline Восточный & 3,1 & 0,052 \\
\hline Северо-восточный & 2,1 & 0,034 \\
\hline
\end{tabular}

Причина более низкого поступления $\mathrm{Pb}$ в почвы Югозападного и Северо-восточного районов может заключаться не только в меньшем числе транспортных магистралей в этих районах и меньшей интенсивности движения на них, но и в направлении воздушных потоков, практически совпадающих с направлением этих магистралей.

Достаточно высокая концентрация $\mathrm{Pb}$ в почвах Bocточного района обусловлена, по-видимому, переносом в этот район загрязняющих аэрозолей преобладающими региональными ветрами из промышленной зоны мегаполиса Санкт-Петербурга [12].

При фоновом для России выпадении $\mathrm{Cd}$, равном 0,12 кг км $^{-2}$ в год, расчетные значения оказываются примерно в 2 раза меньше фоновых. Однако за последние несколько лет наблюдается устойчивая тенденция увеличения выпадения $\mathrm{Cd}$ на территории области. Пространственное распределение выпадения Cd в 1999 г. на Ленинградскую область (табл. 2) было аналогичным выпадению $\mathrm{Pb}$. Следует отметить, что на территориях, прилегающих с Санкт-Петербургу 
(Пригородный район), зарегистрировано выпадения $\mathrm{Cd}$, равное 0,07 кг км ${ }^{-2}$ в год.

От собственных источников на территорию области по данным [15] в 1999 г. поступило немногим более трети $\mathrm{Cd}$. Следовательно, основным источником загрязнения территории области Сd является его импорт из стран Западной Европы и Прибалтики путем трансграничного переноса воздушными потоками в верхней атмосфере Принято считать, что техногенное загрязнение почв $\mathrm{Cd}$ обусловлено результатами металлургических процессов и металлообработки на промышленных предприятиях. Не менее значительное количество $\mathrm{Cd}$ может поступать в окружающую среду при внесении в почвы сельскохозяйственного назначения большого количества минеральных удобрений и ядохимикатов [22]. Особенно широко агрохимические технологии в настоящее время используются в западноевропейских странах.

На территории Ленинградской области не отмечено выпадение $\mathrm{Hg}$ за счет трансграничного его переноса из соседних регионов. Загрязнение окружающей среды этим токсикантом обусловлено региональными источниками. При этом наиболее загрязненным является Пригородный район, где нагрузка $\mathrm{Hg}$ на почву близка к критической, равной 0,06 кг'км ${ }^{-2} \mathrm{Hg}$ в год. Основным поставщиком $\mathrm{Hg}$ в почвах этого района следует считать несанкционированные свалки бытовых и промышленных отходов, расположенные в большом количестве по всему периметру внешней границы Санкт-Петербурга. На этих свалках в большом количестве находятся промышленные и медицинские измерительные приборы, содержащие $\mathrm{Hg}$, а также всевозможные «ртутные светильники».

Подобная картина наблюдается также вблизи ряда промышленных центров области - городов Кириши, Бокситогорска, Волхова, а также Кингисеппа и Сланцев. Роль трансграничного переноса в этом случае весьма невысока, поскольку в Северо-восточном районе и на Карельском перешейке присутствие $\mathrm{Hg}$ в почвах не зарегистрировано.

Интенсивная урбанизация мегаполиса СанктПетербурга и ускоренное промышленное развитие Западного и Центрального районов Ленинградской области уже в ближайшее десятилетие, вероятно, приведет к ухудшению экологической обстановки на территории области (особенно в Северо-восточных и Восточных районах), если не будут применены действенные меры по защите окружающей среды от воздействия на нее вредных антропогенных атмосферных аэрозолей.

Следует отметить, что почвы Ленинградской области характеризуются низкой экологической буферностью и чрезвычайно высокой чувствительностью к антропогенным нагрузкам. Наибольшую озабоченность вызывает загрязнение почв тяжелыми металлами, в первую очередь свинцом $(\mathrm{Pb})$, кадмием $(\mathrm{Cd})$ и ртутью $(\mathrm{Hg})$. Неумеренное поступление тяжелых металлов в окружающую среду приводит к серьезным негативным последствиям. Включаясь в биохимические циклы, они оказывают пагубное влияние на живущие в почве микроорганизмы, а также растения, животных и человека. Так известна вызывающая тревогу зависимость повышения уровня накопления тяжелых металлов при продвижении их по трофическим цепям, представляющая существенную опасность для высших организмов, в частности, для человека.

\section{Органический компонент аэрозолей}

Спектральные измерения в инфракрасной области спектра фильтровых проб аэрозолей позволили обнаружить высокую долю органического вещества в приземных аэрозолях Ленинградской области, в первую очередь в летнее время $[1,2]$.

Органический компонент аэрозолей обусловлен либо их выделением растительностью, либо образованием в результате хозяйственной деятельности человека. В первом случае мы имеем различного рода терпены, ответственные за голубые дымки над лесами. Во втором случае количество и разнообразие органических соединений значительно больше. Например, химический анализ проб городских аэрозолей, взятых в г. Генте с использованием методик газовой хроматографии и масс-спектрометрии, выявил присутствие примерно 100 различных органических соединений, состав которых отражал, прежде всего, свойства продуктов автомобильных выбросов. В число преобладающих органических соединений входили в течение всего года н-алканы и жирные кислоты, причем относительное содержание различных органических компонентов характеризовалось наличием отчетливого годового хода. Наличие проб, полученных в разное время года, позволило проследить за изменениями состава аэрозолей в течение года [23]. Для изменчивости содержания н-алканов в аэрозолях летом было типично проявление воздействия биогенных выбросов, обусловленных растительностью [26].

Характерная особенность годового хода содержания жирных кислот состояла в наличии более низкой концентрации ненасыщенных жирных кислот летом, чем зимой, что могло быть связано с происходящими летом процессами более интенсивного окисления ненасыщенных жирных кислот. Содержание дикарбоновых кислот и связанных с ними продуктов, которые возникают, по-видимому, за счет окисления углеводородных соединений и жирных кислот, была максимальной летом. В некоторых случаях подобные соединения могли быть обнаружены только летом, достигая максимальной концентрации в жаркие летние дни при температуре воздуха выше $25^{\circ} \mathrm{C}$ и повышенной концентрации приземного озона. Некоторые из обнаруженных соединений являются индикаторами сгорания древесины и продуктами гидролиза лигнина. Результаты измерений их содержания свидетельствуют о том, что вклад сжигания древесины более значителен зимой, чем летом, и отражают тот факт, что в формирование органических аэрозолей вносит вклад сжигание как твердой (лиственные породы), так и мягкой древесины, но зимой преобладает вклад твердой древесины. Повышение концентрации зимой характерно также для полиароматических соединений [17].

Особый интерес представляют результаты исследований временных вариаций содержания органической компоненты аэрозолей. Максимум содержания органических веществ в составе аэрозолей отмечается в июне (рис. 6). При этом наблюдается заметный суточный ход объемной концентрации органики с максимумом в 17-18 часов (рис. 7).

Основная доля органических соединений содержится в частицах с $\mathrm{r}<0,1$ мкм. Исключение составляют периоды бурного пыления растительности, когда концентрация органических веществ возрастает примерно на 2 порядка (до 10 мкг/ м3), а размеры частиц, содержащих органические вещества, превышают 1 мкм. Для данных 


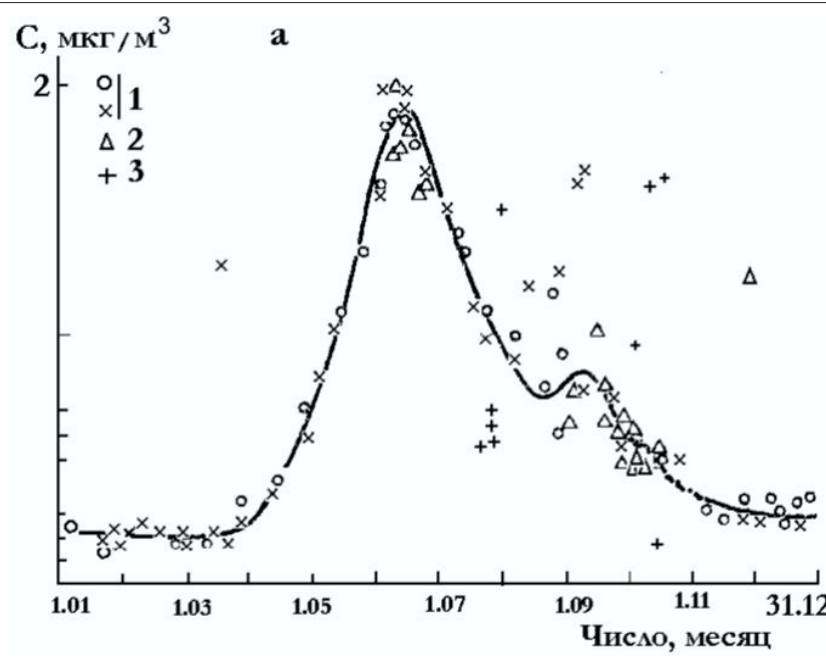

Рис. 6. Среднесуточное содержание органических веществ в приземных аэрозолях, мкг/ $\mathrm{M}^{3}$ : 1 - Старый Петергоф (Ленинградская область); 2 - Томск; 3 - Кемерово

осенних измерений периода 1985-1989 гг. характерно малое содержание в аэрозолях органических компонент. Хотя количественный анализ на органику тогда не проводился, можно считать, что количество органических

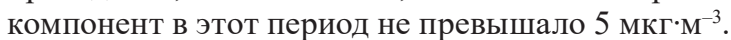

\section{Заключение}

Состояние среды в Ленинградской области в большой степени зависит от процессов взаимодействия с ней различных естественных и антропогенных аэрозолей, от интенсивности их образования и от физикохимических свойств, в частности, влияющих на фазовые переходы воды в атмосфере и земной поверхности.

$\mathrm{B}$ результате химических реакций загрязняющих веществ друг с другом и атмосферными газами
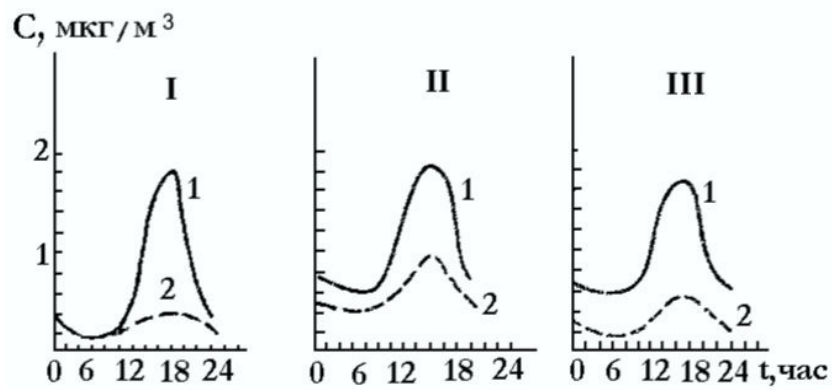

Рис. 7. Суточные изменения содержания органических веществ в приземных аэрозолях.

I - Рыльск, август 1979 г.:

1 - ясные дни; 2 - пасмурные дни;

II - Ленинградская область, 1978-1982 гг.:

1 - май-июнь, ясные дни; 2 - сентябрь-октябрь: ясные дни; III - Томск, 1970-1972 гг.:

1 - июнь, ясные дни; 2 - сентябрь-октябрь, пасмурные дни

при солнечном освещении в атмосфере могут образовываться вещества с более вредными для окружающей среды и человека свойствами, чем первоначально выброшенные в атмосферу.

Для Ленинградской области характерно наличие больших водных поверхностей, что способствует очищению приземных слоев атмосферы от загрязняющих веществ и смягчению температурных контрастов. Однако присутствие мощных источников загрязнений от ряда производств, например, в СанктПетербурге, Киришах, Тихвине, Сланцах, Кингиссепе, Светогорске, Бокситогорске, Сясьстрое, создает кратковременные экологические угрозы. Это требует непрерывного мониторинга состояния атмосферы.

\section{Литература}

\section{Список русскоязычной литературы}

1. Андреев СД, Ивлев ЛС. Временная и пространственная изменчивость оптических и аэрозольных характеристик в атмосфере. Оптика атмосферы и океана. 1997;10(12):1440-62.

2. Васильев АВ, Ивлев ЛС. Эмпирические модели и оптические характеристики аэрозольных ансамблей двухслойных сферических частиц. Оптика атмосферы и океана. 1997;10(8):856 65.

3. Дмоховский ВИ, Ивлев ЛС, Иванов ВН. Самолетные измерения вертикальной структуры атмосферного аэрозоля по программе КЭНЭКС. Труды ГГО. 1972;(276):37-42.

4. Донченко ВК, Ивлев ЛС. Об идентификации аэрозолей различного происхождения. В кн.: Третья международная конференция «Естественные и антропогенные аэрозоли». Сборник трудов. СПб.: НИИ химии СПбГУ; 2003. c. 4152 .
5. Ивлев ЛС. Химический состав и структура атмосферных аэрозолей. Л.: Изд-во ЛГУ; 1982.

6. Ивлев ЛС. Начала физики погодо- и климатообразования. СПб.: ВВМ; 2009.

7. Ивлев ЛС. Гетерогенная химия нижней атмосферы. Проблемы физики атмосферы. 1997;(20):54-80.

8. Ивлев ЛС, Васильев АВ, Белан БД. Оптикомикрофизические модели городских аэрозолей. В кн.: Третья международная конференция «Естественные и антропогенные аэрозоли». Сборник трудов. СПб.: НИИ химии СПбГУ; 2003. c. 161-70.

9. Ивлев ЛС, Довгалюк ЮА. Физика атмосферных аэрозольных систем. СПб: СПбГУ; 2000.

10. Кондратьев КЯ, Ивлев ЛС. Климатология аэрозолей и облачности. Природные и техногенные аэрозоли. СПб.: Изд-во ВВМ; 2008.

11. Контроль химических и биологических параметров окружающей среды. СПб.: Эколого- 
аналитический информационный центр «Союз»; 1998.

12. Кудряшов ВИ. Анализ элементного состава атмосферных аэрозолей физическими методами. Проблемы физики атмосферы. 1997;(20):97-130.

13. Любовцева ЮС, Лактионов АТ, Малкевич MC. Некоторые статистические характеристики микроструктуры аэрозоля в приземном слое атмосферы. Изв АН СССР Физика атмосферы и океана. 1973:9(11):1161-8.

14. Марчук ГИ. Математическое моделирование в проблеме окружающей среды. М.; 1982.

15. О состоянии окружающей среды в СанктПетербурге и Ленинградской области в 1998 году. Аналитический обзор. Раздел I. Атмосферный воздух. СПб.: Ленкомприрода; 1999.

16. Рышкевич ТН, Михайлов ЕФ, Власенко СС. Структурная изменчивость сажевых частиц различной природы. Оптика атмосферы и океана. 1996;9(6):853-7.

17. Салин ВИ. Модель трансграничного переноса аэрозолей на территорию Ленинградской области. В кн.: Третья международная конференция «Естественные и антропогенные аэрозоли». Сборник трудов. СПб.: НИИ химии СПбГУ; 2003. с. 1914.

18. Расул С, ред. Химия нижней атмосферы. М.: Мир; 1976.

\section{Общий список литературы/Reference list}

1. Andreyev SD, Ivlev LS. [Temporal and spatial variability of optical and aerosolic characteristics of the atmosphere] Optika Atmosfery i Okeana. 1997;10(12):1440-62. (In Russ.)

2. Vasilyev AV, Ivlev LS. [Empirical models and optical characteristics of aerosol ensembles of two-layered spherical particles]. Optika Atmosfery i Okeana. 1997;10(8);856-65. (In Russ.)

3. Dmokhovski VI, Ivlev LS, Ivanov VN. [Aircraft-assisted measurements of the vertical structure of atmospheric aerosol within the framework of KENEKS Program]. Trudy GGO. 1972;(276):37-42. (In Russ.)

4. Donchenko VK, Ivlev LS. [On identification of aerosols having different origins]. In: Tretiya Mezdunarodnaya Konferentsia "Yestestvennye i Antropogennye Aerozoli. Saint Petersburg: NII Khimiii SPbGU; 2003. p.41 52. (In Russ.)

5. Ivlev LS. Khimicheskiy Sostav i Struktura Atmosfernykh Aerozoley. Leningrad: LGU; 1982.

6. Ivlev LS. Nachala Fiziki Pogodo- i Klimataobrazovaniya. Saint Petersburg; VVM, 2009.

7. Ivlev LS. [Heterogenic chemistry of lower atmosphere]. Problemy Fiziki Atmosfery, 1997;(20):5480. (In Russ.)

8. Ivlev LS,Vasilyev AV, Belan BD. [Optic-microphysical models of urban aerosols]. In: Tretiya Mezhdunarodnaya Konferentsia "Yestestvennye i Antropogennye Aerozoli". Saint Petersburg: NII Khimii SPbGU; 2003. p. 161-70. (In Russ.)

9. Ivlev LS, Dovgalyuk YuA. Fizika atmosfernich aerozolnich system. Saint Petersburg, SPbGU; 2000.

10. Kondratyev KYa, Ivlev LS. Klimatologiya Aerozoley i Oblachnosti. Saint Petersburg; VVM, 2008.
11. Kontrol Khimicheskich i Biologicheskich Parametrov Okruzayuschey Sredy. Saint Petersburg: Ekologo-Analiticheskiy Tsentr Soyuz, 1998.

12. Kudryashov VI. [Analysis of the element composition of atmospheric aerosols using physical methods]. Problemy Fiziki Atmosferyi. 1997;(20):97130. (In Russ.)

13. Lubovtseva YuS, Laktionov AT, Malkevich MS. [Some statistical characteristics of the microstructure of aerosols in the ground layer of atmosphere]. Izv AN SSSR Fizikia Atmosferi i Okeana. 1973;9(11):1161-8

14. Marchuk GI. Matematicheskoye Modelirovaniye v Probleme Okruzhayuschey Sredy. Moscow; 1982.

15. O Sostoyanii Okruzhayuschey Sredi v SanktPeterburge i Leningradskoy Oblasti v 1998 Godu. Analiticheskiy Obzor. Razdel I. "Atmosfernyi Vozdukh". Saint Petersburg: Lenkompriroda; 1999.

16. Ryshkevich TN, Mikhailov YeF, Vlasenko SS. [Structural Variability of soot particles of different origins]. Optika Atmosferi i Okeana. 1996;9(6):853-7. (In Russ.)

17. Salin VI. [A model of the transboundary passage of aerosols to Leningrad Pblast territory]. In: Tretiya Mezhdunarodnaya Konferentsiya "Yestestvennye i Antropogennye Aerozoli" Sbornik Trudov. Saint Petersburg; NII Khimii SPbGU; 2003. p. 191-4. (In Russ.)

18. Rasul S, ed. Khimiya Nizhney Atmosfery. Moscow: Mir;1976.

19. Hidy GM, ed. Aerosols and Atmospheric Chemistry. New York: Academic Press; 1972.

20. Blifford JH, ed. Particulate Models: Their Validity and Application. Boulder CO.: NCAR; 1970.

21. Graedel TE, Farrow LA, Weber TA. Kinetic studies of the photochemistry of the urban troposphere. Atm Environ. 1976;10:1095-103.

22. Kondratyev KYa, Ivlev LS, Krapivin VF, Varotsos CA. Atmospheric Aerosol Properties, Formation, Processes and Impacts. Chichester, UK: Springer Publ. Praxis; 2006.

23. Kubátova A, Vermeylen R, Claes M, Cafmeyer J, Maenhaut W. Organic compounds in urban aerosols from Gent, Belgium: Characterization, sources, and seasonal differences. J Geophys Res. 2002;107:5/1-5/12.

24. Meszaros E. Fundamentals of Atmospheric Aerosol Chemistry. Budapest: Akademia Kiado; 1999.

25. Neusüss C, Wex H, Birmili W. et al. Characterization and parameterization of atmospheric particle number, mass, and chemical-size distributions in central Europe during LACE 98 and MINT. J Geophys Res. 2002;107:9/1-9/13.

26. Pun BK, Griffin RJ, Seigneur C, Seinfeld H. Secondary organic aerosol. 2. Thermodynamic model for gas/particle partitioning of molecular constituents. J Geophys Res. 2002;107:4/1-4/15.

27. Seinfeld JH, Pandis SN. Atmospheric Chemistry and Physics. From Air Pollution to Climate Change. New York; Wiley-Interscience; 1997.

28. Wexler AS, Clegg SL. Atmospheric aerosol models for systems including the ions $\mathrm{H}+, \mathrm{NH} 4+$, $\mathrm{Na}+$, SO42-, NO3-, Cl-, Br- and H2O. J Geophys Res. 2002;107:14/1-14/14. 